\title{
Transition Economies During Global Economic Crisis: A Difference in Differences Approach $^{3}$
}

\author{
Article history: \\ Received: 20 April 2014 \\ Sent for revision: 9 May 2014 \\ Received in revised form: 17 July 2014 \\ Accepted: 23 July 2014 \\ Available online: 1 November 2014
}

\begin{abstract}
This paper describes how the global economic crisis impacted economies in transition, which in terms of GDP decline, were the most negatively impacted economies in the world. Therefore the region went from a growth rate of around $8.4 \%$ in 2007 to $-3.9 \%$ in 2009. The aim of this paper is to determine which countries depending on the level of progress in the transitional reforms implementation (measured by transition indicator) were more exposed to the effects of the global economic crisis, i.e. which countries in the five-year period 2009-2013 faster showed progress as measured by the economic growth rate. The research is based on difference in differences (DinD) methodology and covered 29 economies in transition. The results showed that economies with lower progress in the way of transition reforms (transition indicator is less than 3) suffered smaller impact of the crisis in its first wave in 2009. In addition, this subset of countries in transition better overcame the crisis in the five-year period 2009-2013 given that they showed 18 percentage points higher cumulative rate of growth in those five years than the transition countries that adopted all the principles of market economy.
\end{abstract}

Key words: transition economies, economic crisis, economic growth, transition indicator, structural reforms

\footnotetext{
${ }^{1}$ Economics Institute, Belgrade, sanja.filipovic@ecinst.org.rs

${ }^{2}$ Economics Institute, Belgrade

3 This paper is a part of research project 179011 and the project No. 47009, financed by the Ministry of Science and Technological Development of the Republic of Serbia.
} 
Filipović S., Miljković M.:Transition Economies During Global Economic Crisis...

\title{
Tranzicione privrede tokom svetske ekonomske krize: pristup razlike u razlikama
}

\begin{abstract}
Apstrakt: Ovaj rad analizira uticaj globalne ekonomske krize na zemlje u tranziciji koje su posmatrano po padu GDP bile najviše pogođene uticajem globalne ekonomske krize. Stoga je stopa rasta za region pala sa $8,4 \%$ u 2007.godini na -3,9\% u 2009.godini. Cilj rada je da utvrdi koje su zemlje u zavisnosti od nivoa napretka u sprovođenju tranzicionih reformi (merenog tranzicionim indikatorom) bile više izložene efektima globalne ekonomske krize, odnosno koje su zemlje u petogodišnjem periodu 2009-2013. godine brže ostvarile napredak mereno stopom ekonomskog rasta. Istraživanje se bazira na pristupu razlike u razlikama i obuhvatilo je 29 zemalja u tranziciji. Rezultati pokazuju je da privrede koje su manje napredovale na putu tranzicionih reformi (tranzicioni indikator manji od 3) su imale manji udar krize u prvom naletu 2009. godine. Pored toga, ova podgrupa zemalja u tranziciji je bolje prevazišla krizu u petogodišnjem periodu 2009-2013 obzirom da su za 18 procentnih poena imale veću kumulativnu stopu rasta u tih pet godina nego zemlje u tranziciji koje su uvele sve principe tržišne privrede.
\end{abstract}

Ključne reči: zemlje u tranziciji, ekonomska kriza, ekonomski rast, tranzicioni indikator, strukturne reforme

\section{Introduction}

It's been a quarter century since centrally planned economy (further transition economies) has started structural reforms on their way toward market economy. By shifting to the market economy system, the transition countries have obliged to respect the market rules and implement the market reforms implying privatization and deregulation of economic activities, the liberalization of international economic trends and the systematic reduction of state functions in economy. This process was compliant to the prevailing neo-liberal concept of the economy, which was based on the ideas of the classical liberal concept promoted since Adam Smith, and in modern conditions, especially supported by Milton Friedman (1962), Hayek (1960), Buchanan (1975), and some other authors. Given the assumption that markets tend towards equilibrium and that deviations are random, this direction advocates reduction of state influence and harsh fiscal austerity measures (Filipović, 2014). Basically it is a laissez-faire policy that is aimed at reducing taxes and growth of private consumption at the expense of government spending. In this context, it is important to note that the very concept originated in the 1980s in terms of growing fiscal crisis of the state and the rise of a new protectionism and the collapse of the dollar standard (Josifidis, 2005). The movement became dominant in the design of economic policy of the United States and 
Filipović S., Miljković M.:Transition Economies During Global Economic Crisis...

Great Britain, and during the 1990s it was implemented in countries in transition.

The transition process was conducted in accordance with the economic stabilization program that included ten main recommendations (Williamson, 1990):

- Establishment of fiscal discipline,

- Definition of the priorities of public expenditure (infrastructure, education, health),

- Tax reform (expansion of the tax base with moderate tax rates),

- Liberalization of interest rates,

- Competitive exchange rate,

- Foreign trade liberalisation,

- Attracting foreign direct investment,

- Privatization of public enterprises,

- Market deregulation, and

- Protection of property rights.

The idea was that introduction of a pure free market would solve market inefficiencies. However, after the first phase of transition, major market failures were identified that could not be ignored. Therefore, the set of recommendations was expanded (fight against corruption, defining financial standards, introducing social protection systems, etc.), and emphasis was placed on institutions development (Williamson, 2004). Although the initial idea was not dropped that the state should not be directly involved in the production process, vast room was recognized for state's activities in this field:

- macroeconomic stability,

- infrastructure development (including public private partnership),

- public health,

- education,

- transfer of technology and R\&D,

- sustainable ecologic development,

- creating a favourable business environment,

- poverty reduction and inequality in income distribution,

- strict supervision and regulation of financial sector, and

- Providing essential public goods, including institutions for the protection of property rights and equal opportunities for all participants.

The empirical analysis of the relationships between market reforms and economic growth in the transition economies was the focus of many academic papers. Some of authors stress the importance of macroeconomic stabilisation and structural reforms for economic growth (De Melo et al.; 2001, 
Filipović S., Miljković M.:Transition Economies During Global Economic Crisis...

Havrylyshyn, van Rooden, 2003) while the others pointed out problem of endogeneity and highlighted that higher rates of growth also induce further economic reforms (Heybey, M. 1999, Berg et al. 1999). Falcetti, Lysenko and Sanfey (2006) concluded that a robust relationship between reforms and growth exists in transition economies with a one-year lag. Pelipas and Chubrik (2008) tested the impact of market reforms on economic growth using the panel data for 26 post-socialist economies over the period between 1989 and 2005 and have found no statistically significant feedback between market reforms and economic growth. At the same time using the different methodology for the same group of countries this relationship is called into question (Radulescu and Barlow, 2002, Babetskii and Campos, 2007).

Over time, the focus of the transitional reforms was shifted from economic growth, but when global economic crisis escalated and an adequate recovery program was needed, the study of correlation between market reforms and economic growth became interesting again. The aim of this paper is to determine which countries, depending on the level of progress in the transitional reforms implementation (measured transition indicator), were more exposed to the effects of the global economic crisis, i.e. which countries during the five-year period 2009-2013 made faster progress as measured by the economic growth rate.

\section{Progress of market reform in transition economies}

Most countries in transition accepted the model of economic shock therapy, which implied the implementation of aggressive privatization program and liberalization of foreign trade and financial flows. The aim is that new private sector generates over $50 \%$ of GDP and employs $2 / 3$ of the workforce. In terms of institutional vacuum participation of the private sector in the gross domestic product (GDP) increased from 10\% in 1990 to 80\% in 1999. Results of the first phase of transition were devastating and the common pattern in all countries was mainly fall in output and poverty (Carlos-Alberto Arrebola Rodriguez, 2011). All countries have gone through a transition recession phase, so the rate of GDP in CEE and SEE countries fell by 15\% compared to 1990, while it declined over $40 \%$ in CIS. In the first ten years Hungary, Latvia, Poland and Slovenia (to some extent Estonia and Lithuania) had uninterrupted growth for several years, while in Bulgaria, Romania and the Czech Republic economic growth was interrupted by the macroeconomic crises. By 2000, the only CEE country that has not reached the 1990 level of GDP was the Czech Republic (World Bank, 2005).

Poland was the first country in transition that dropped the radical reform model and in 1993/94 created its own model of reforms when it achieved significantly higher economic performance. More successful were the countries in transition that have gradually built up the institutional framework 
Filipović S., Miljković M.:Transition Economies During Global Economic Crisis...

and led development policy towards the creation of a new private sector which required the following: maximally simplified procedure for establishing new companies, tax incentives, support for financial sector, improvement of the overall investment and business environment. On the other hand, the reforms entailed the state's support during the restructuring and/or closure of enterprises, firmer financial discipline, putting the social functions outside enterprises, fostering competition. The winners of the second phase of the transition were from a new entrepreneurial class, and the losers - those in old economy sectors and (partly) public sector.

In the late 1990s, other countries also entered the second phase of reforms based on a gradualist approach. The mistakes of the first phase indicated that the state has a proactive role in development, and that it is necessary to strike a balance between the role of the state and the market, primarily in regulation of financial markets, education, infrastructure, distribution, strategy to reduce poverty and unemployment. In the second phase of transition, the focus was on institutions development, since it was assumed that institutions are the key for development, and the development of democracy contributes to the transparency and credibility of the market economy.

Oriented toward market economy process, EBRD created specific group of transition indicators in order to evaluate the progress in transition. Obtained scores actually indicate evaluation of progress in each specific country regarding the following fields:

1. Large scale privatisation,

2. Small scale privatisation,

3. Governance and enterprise restructuring,

4. Price liberalisation,

5. Trade and foreign exchange system, and

6. Competition policy.

The basis of the transition indicator score was methodology initially introduced by the 1994 Transition Report, but further developed in detail by later reports. In this way reform developments were recorded in each transition country since 1989. Achieved progress was measured based on standards that are applied in market economies, having in mind that there is no perfect market economy and no ceiling for transition.

Second half of the decade was marked by rapid development of structural reforms, which were measured by using the average of EBRD transition indicators from six countries. During this period price liberalisation, smallscale privatisation and the opening-up of trade and foreign exchange markets were mostly completed. After 2000, economic reform stagnated in most countries in transition, with the exception of the Western Balkans, where reform was supported by the EU accession process. In less developed 
Filipović S., Miljković M.:Transition Economies During Global Economic Crisis...

economies in transition, improvements in economic institutions ran in parallel, while in more advanced economies (particularly the new EU member states), economic crisis and the savings led to harsh criticism and drop in support for the implementation of market-oriented reforms.

The following Figure 1 indicates the average values in all transition economies regarding six indicators. The average values are presented on a scale 1 to $4+$, where the highest score represents the standards of an industrialized market economy and the lowest score indicates little or no change from a rigid centrally planned economy. The average values are obtained by rounding down, while "+" and "-" ratings are treated by adding 0.33 and subtracting 0.33 from the full value.

Figure 1. Progress in transition measured by average transition indicator

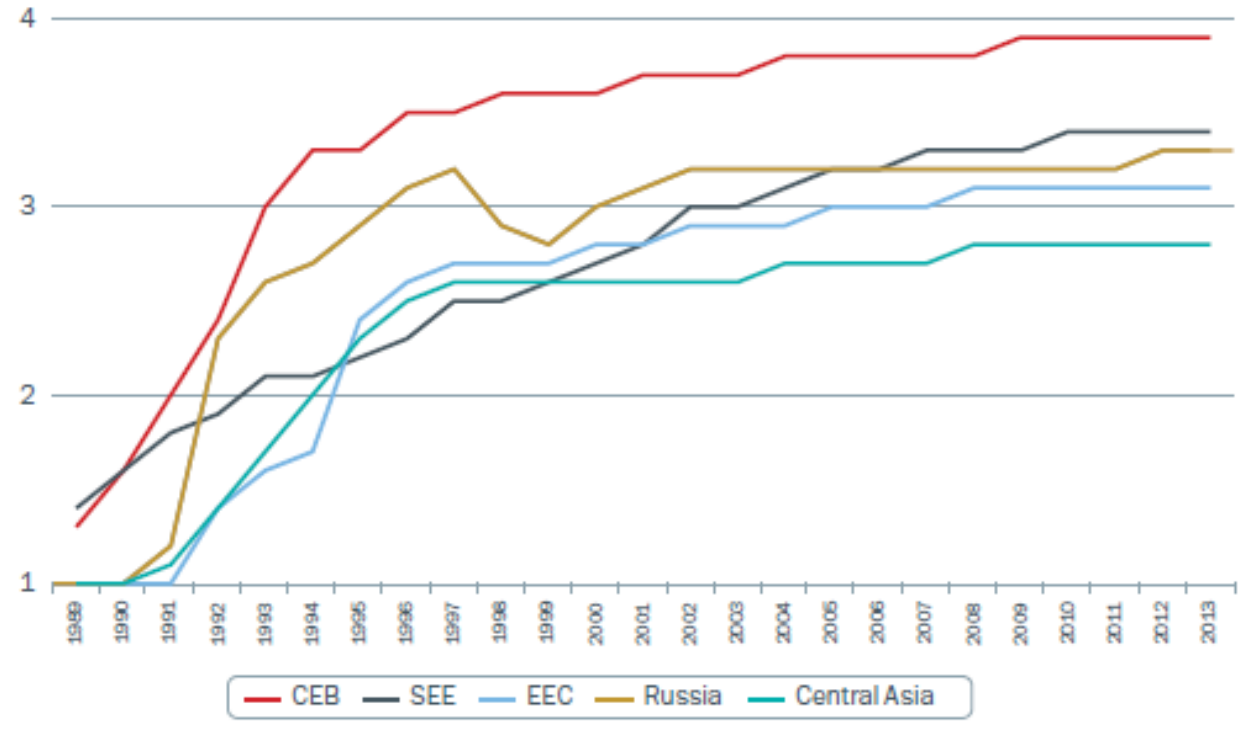

Source: Transition Report 2013, EBRD

The EU accession process has led to an influx of capital due to the introduction of institutional provisions, which was important for the economy. After 2000, GDP growth in transition economies confirmed their economic stability and improvement. Two decades ago, the per capita income in many countries in transition (excluding the least developed countries of Central Asia and the Western Balkans) was between $15 \%$ and $45 \%$ of the EU15 average, measured in purchasing power. Relative income in most of these countries has increased by about 20\% and now amounts to between 35\% and $65 \%$ of the EU15 average. Czech Republic and Slovenia are above this level, with 
Filipović S., Miljković M.:Transition Economies During Global Economic Crisis...

GDP per capita above $70 \%$ of the EU15 average, while Ukraine is below this level (EBRD, 2013).

Structural reforms are aimed at creating a favourable business climate that will attract investments. Economies in transition are a good example as they obtained capital through FDI to finance its growth and convergence. The value of FDI as a share of GDP jumped in SEE (without Turkey) from $14 \%$ to $40 \%$ in the period $2000-2008$. The value of FDI in the new EU member states was high at $30-50 \%$ of GDP. Before the global economic crisis built up, the value of FDI was at the same level in the CIS, $16 \%$, but the different values could be found in Georgia and Turkmenistan 50\%, and in Uzbekistan, Belarus, Russia, about 10\%.

In the period before the crisis, the economies in transition experienced economic growth due to several factors: FDI and bank credits, the growth in domestic demand, and the integration in trade and financial flows of the EU. In most transition economies that were not members of the EU, foreign trade and financial flows got liberalized as a result of EU accession. This and the fact they were not exposed to risky mortgages protected them from the global financial crisis until 2008. On the other hand, the signs of the crisis were noticeable in decline of capital inflows through FDI and bank loans, and export revenues and remittances (Filipovic, 2012).

Global GDP dropped by $2.05 \%$ in 2009 , which had not happened for 50 years (Singh \& Zammit, 2010). However, this drop was double in the transition economies, i.e. from $8.4 \%$ in 2007 to $-3.9 \%$ in 2009 . In terms of GDP, it can be concluded that not all countries reacted to the crisis in the same manner. The transition indicator was the highest in the new EU member states, implying the negative influence from the global economic crisis. This impact was not caused by high share of the sub-prime assets, but by their dependence on external capital to finance and their trade with Western Europe.

When the global crisis intensified, the transition economies showed how vulnerable they were due to being dependent on FDI and bank loans, which transformed into large current account deficits (e.g. deficit in Latvia was 22\% GDP in 2007). After 2005, current account deficit increased, and in 2007 many new member EU states, SEE countries and the non-resource CIS indicated deficit higher than 10\% of GDP. However, surpluses of $10 \%$ of GDP were showed by the resource rich CIS (including Russia) but they dropped in 2009 as a result of commodity prices decline.

Remittances prove to be of great importance for transition economies as they have inflows higher than $5 \%$ of GDP, while developing countries have remittances of $2 \%$ of GDP. As an example, Tajikistan and Moldova had precrisis remittances over $30 \%$ of GDP. Another result of the crisis was trade 
Filipović S., Miljković M.:Transition Economies During Global Economic Crisis...

flows decline, because of the demand decrease. Therefore, many countries changed their terms of trade. Largest fall in terms of trade was experienced by oil exporters, since the energy price significantly declined and this greatly influenced the energy-rich CIS. Therefore, economic welfare of the country also fell as GDP is calculated without taking into account the changes in price (Shelburne, 2010).

Significant decline of all three main external elements of demand caused the fall of demand as well which adversely influenced the economic growth. Albania and Poland were the only European countries that avoided recession during crisis thanks to depreciation of their currencies, i.e. Polish zloty depreciated by $32 \%$ (versus the US\$) from its 2008 peak value, and Albanian lek depreciated by $12 \%$ per cent based on a monthly average in 2008-2010. Currencies in most transition economies fell by approx. 20\%, which encouraged competitiveness, due to foreign currency loans, but aggravated the debt issues.

During the crisis, many countries had to seek help from the IMF, such as seven CIS countries (Armenia, Belarus, Georgia, Kyrgyzstan, Moldova, Tajikistan, and Ukraine), two SEE countries (Bosnia and Herzegovina, and Serbia) and four new EU member states (Hungary, Latvia, Poland, and Romania). At the outbreak of the global economic crisis, the IMF advised the application of highly expansionary monetary and highly expansionary fiscal policy. Such a package of measures is applied in the USA, the UK, Germany, France, Italy and other countries of the euro zone, but most of the programs implemented in transition economies were contractionary in terms of their fiscal, monetary and public wage conditionality. The only countries with expansionary fiscal policies integrated in their plan were Armenia and Georgia, while Serbia was the only country with allowed monetary expansion. Countries that did not apply an IMF program could implement stronger counter-cyclical policies. The Russian fiscal expansion was high due to spending increase by $30 \%$ and tax revenues decrease by $30 \%$, while the difference was financed from its reserve fund (Shelburne, 2009).

\section{Methodology and data}

The main aim of the paper is to examine firstly, whether there is a significant difference in the intensity of the shock in 2009 between countries which advanced on their path of reforms toward market economy and others which are at the beginning of the reform process, and secondly, whether there is a significant difference in overcoming negative effects of global economic crisis between the mentioned groups of countries in the five-years period after the shock. 
Filipović S., Miljković M.:Transition Economies During Global Economic Crisis...

Thereby, progress in reforms is measured by the transition indicator developed by the EBRD. Real GDP growth rate in 2009 serves as an indicator of the intensity of the short-term shock at the very beginning of the crisis, while cumulative real GDP growth rate in the period 2009-2013 serves as a measure of success in overcoming negative effects of the crisis.

The research is carried out by using so called difference in differences (DinD) methodology. The essence of DinD methodology consists in dividing the sample into two parts and examining whether these two parts react differently to some treatment. The criterion for partition of the sample, which consists of 29 transition countries, is the value of the transition indicator. The treatment in our research is related to the global economic crisis, and, as already explained, is measured by real GDP growth rate in 2009 and cumulative real GDP growth rate in the period 2009-2013.

Therefore, in order to estimate whether there is a significant difference in the intensity of the shock in 2009 between transition countries with better progress in implementation of transition reforms and those with worse progress, we estimate the following model:

$Y_{i t}=\beta_{0}+\beta_{1}{ }^{*} X_{i}+\beta_{2}{ }^{*} T_{t}+\beta_{3}{ }^{*} X_{i}{ }^{*} T_{t}+\varepsilon_{i t}$,

Where:

$Y_{i t}=$ real GDP growth rate for the observed group of countries $i$ in the time period $t(\mathrm{t}=0$ for $2008, \mathrm{t}=1$ for 2009),

$X_{i}=$ dummy variable which takes the value 1 for countries with transition reform indicator higher than 3 and 0 for countries with transition reform indicator lower than 3 ,

$T_{t}=$ dummy variable which takes the value 1 for the year 2009 when the first effects of the crisis appeared and 0 for the pre-crisis year 2008,

$\mathrm{X}_{\mathrm{i}}^{*} \mathrm{~T}_{\mathrm{t}}=$ dummy variable which denotes the interaction of dummy variables $\mathrm{X}_{\mathrm{i}}$ and $T_{t}$, and takes value 1 for the countries with transition indicator higher than 3 in the post-crisis period,

$\varepsilon_{\mathrm{it}}=$ random error of the model.

By applying ordinary least squares method, we calculate the estimated values of the parameters $\beta_{0}, \beta_{1}, \beta_{2}$ and $\beta_{3}$. If we denote $\mu_{\mathrm{it}}$ as an average value of the variable $Y_{i t}$ for the group of countries $i$ in the time period $t$, then the estimated values of the parameters can be interpreted as described in the Table 1. 
Filipović S., Miljković M.:Transition Economies During Global Economic Crisis...

Table 1. Interpretation of the estimated values of parameters

\begin{tabular}{|l|l|}
\hline \multicolumn{1}{|c|}{$\begin{array}{c}\text { Estimated value of the } \\
\text { parameter }\end{array}$} & $\begin{array}{l}\text { Interpretation of the estimated value of the } \\
\text { parameter }\end{array}$ \\
\hline$\widetilde{\beta_{0}}=\mu_{00}$ & $\begin{array}{l}\text { The average real GDP growth rate of } \\
\text { countries with worse transition progress in } \\
\text { the year 2008. }\end{array}$ \\
\hline$\widetilde{\beta_{1}}=\mu_{10}-\mu_{00}$ & $\begin{array}{l}\text { The difference between the average real } \\
\text { GDP growth rate of countries with better and } \\
\text { worse transition progress in the year 2008. }\end{array}$ \\
\hline$\widetilde{\beta_{2}}=\mu_{01}-\mu_{00}$ & $\begin{array}{l}\text { The difference between the average real } \\
\text { GDP growth rate in the year 2009 and 2008 } \\
\text { for the group of countries with worse } \\
\text { transition progress. }\end{array}$ \\
\hline$\widetilde{\beta_{a}}=\left(\mu_{11}-\mu_{10}\right)-\left(\mu_{01}-\mu_{00}\right)$ & $\begin{array}{l}\text { The difference between the change in } \\
\text { average real GDP growth rate in the } \\
\text { observed period between the group of } \\
\text { countries with better and worse transition } \\
\text { progress. }\end{array}$ \\
\hline
\end{tabular}

Source: Author's calculation

The most important parameter of the model is just $\beta_{3}$ which denotes so called DinD estimator. The statistical significance of the DinD estimator indicates the existence of significant correlation between the progress in implementation of transition reforms and the intensity of the shock in 2009 measured by real GDP growth rate. Therefore, in the case of statistical significance of this parameter, we can conclude that there is a significant difference between the intensity of the shock in 2009 in the countries with the better and worse progress in transition reforms.

Beside the differences in the intensity of the shock in the first wave of the global economic crisis in 2009, the paper analyses the existence of the differences in overcoming negative effects of global economic crisis in the five-years period after the first shock. Therefore, we estimate the modified model as follows:

$Y^{\prime}{ }_{i t}=Y_{0}+Y_{1}{ }^{*} X_{i}+Y_{2}{ }^{*} T^{\prime}{ }_{t}+Y_{3}{ }^{*} X_{i} * T^{\prime}{ }_{t}+\varepsilon_{i t}$

Where:

$Y_{\text {it }}^{\prime}=$ cumulative real GDP growth rate for the observed group of countries $i$ in the time period $t(\mathrm{t}=0$ for 2008 and $\mathrm{t}=1$ for the period 2009-2013),

$\mathrm{T}_{\mathrm{t}}{ }_{\mathrm{t}}=$ dummy variable which takes the value 1 for the period 2009-2013 and 0 for the pre-crisis year 2008. 
Filipović S., Miljković M.:Transition Economies During Global Economic Crisis...

By applying ordinary least squares method, we calculate the estimated values of the parameters $Y_{0}, Y_{1}, Y_{2}$ and $Y_{3}$, which can be interpreted analogous with the explanation in the Table 1.

Table 2. The sample of 29 transition countries with appropriate data

\begin{tabular}{|c|c|c|c|c|c|}
\hline Country & $\begin{array}{l}\text { GDP } \\
\text { growth } \\
\text { rate in } \\
2008\end{array}$ & $\begin{array}{l}\text { GDP } \\
\text { growth } \\
\text { rate in } \\
2009\end{array}$ & $\begin{array}{l}\text { Cumulative } \\
\text { GDP growth } \\
\text { rate in the } \\
\text { period } \\
2009-2013\end{array}$ & $\begin{array}{l}\text { Transition } \\
\text { Reform } \\
\text { Index }\end{array}$ & $\mathbf{X}_{\mathbf{i}}$ \\
\hline Albania & 7.5 & 3.3 & 12.8 & 3.4 & 1 \\
\hline Armenia & 6.9 & -14.2 & 1.6 & 3.5 & 1 \\
\hline Azerbaijan & 10.8 & 9.3 & 24.1 & 2.9 & 0 \\
\hline Belarus & 10.3 & 0.1 & 16.9 & 2.1 & 0 \\
\hline $\begin{array}{l}\text { Bosnia and } \\
\text { Herzegovina }\end{array}$ & 5.6 & -2.7 & -1.0 & 3.0 & 0 \\
\hline Bulgaria & 6.2 & -5.5 & -2.0 & 3.7 & 1 \\
\hline Croatia & 2.1 & -6.9 & -11.9 & 3.6 & 1 \\
\hline Estonia & -4.2 & -14.1 & 1.2 & 4.1 & 1 \\
\hline Georgia & 2.3 & -3.8 & 7.6 & 3.5 & 1 \\
\hline Hungary & 0.9 & -6.8 & 20.1 & 4.0 & 1 \\
\hline Kazakhstan & 3.3 & 1.2 & -4.9 & 3.1 & 1 \\
\hline $\begin{array}{l}\text { Kyrgyz } \\
\text { Republic } \\
\end{array}$ & 7.6 & 2.9 & 29.9 & 3.4 & 1 \\
\hline Latvia & -2.8 & -17.7 & 18.9 & 3.8 & 1 \\
\hline Lithuania & 2.9 & -14.8 & -6.3 & 3.9 & 1 \\
\hline $\begin{array}{l}\text { FYR } \\
\text { Macedonia }\end{array}$ & 5.0 & -0.9 & -1.8 & 3.5 & 1 \\
\hline Moldova & 7.8 & -6.0 & 16.2 & 3.3 & 1 \\
\hline Mongolia & 8.9 & -1.3 & 55.0 & 3.4 & 1 \\
\hline Montenegro & 6.9 & -5.7 & 0.5 & 3.1 & 1 \\
\hline Poland & 5.1 & 1.6 & 14.2 & 3.9 & 1 \\
\hline Romania & 7.3 & -6.6 & -1.7 & 3.6 & 1 \\
\hline Russia & 5.2 & -7.8 & 5.2 & 3.2 & 1 \\
\hline Serbia & 3.8 & -3.5 & -0.1 & 3.1 & 1 \\
\hline $\begin{array}{l}\text { Slovak } \\
\text { Republic }\end{array}$ & 5.8 & -4.9 & 5.1 & 4.0 & 1 \\
\hline Slovenia & 3.4 & -7.9 & -9.5 & 3.6 & 1 \\
\hline Tajikistan & 7.9 & 3.9 & 37.2 & 2.8 & 0 \\
\hline Turkey & 0.7 & -4.8 & 20.4 & 3.5 & 1 \\
\hline Turkmenistan & 14.7 & 6.1 & 62.7 & 1.7 & 0 \\
\hline Ukraine & 2.3 & -14.8 & -6.5 & 3.3 & 1 \\
\hline Uzbekistan & 9.0 & 8.1 & 48.4 & 2.3 & 0 \\
\hline
\end{tabular}

Source: EBRD, www.ebrd.com 
Filipović S., Miljković M.:Transition Economies During Global Economic Crisis...

After the estimated values of the parameters of the model is being calculated, we are going to check the underlying assumptions of the general linear regression model, which are valid also in the case of DinD regression, in order to be sure that the calculated estimated values are the best linear unbiased estimations.

The observed sample includes 29 transition countries. In Table 2, there are presented data about real GDP growth rate in 2008 (Y0) and 2009(Y1), cumulative real GDP growth rate in the period 2009-2013 (Y1'), transition reforms index, as well as values of the dummy variable $\mathrm{Xi}$.

\section{Empirical results of research and discussion}

The empirical results calculated by applying ordinary least squares method on the equation (1):

$$
Y_{i t}=\beta_{0}+\beta_{1}{ }^{*} X_{i}+\beta_{2}{ }^{*} T_{t}+\beta_{3}{ }^{*} X_{i}^{*} T_{t}+\varepsilon_{i t},
$$

are presented in the Table 3 .

Table 3. The empirical results on the difference in the intensity of the shock in 2009

Dependent Variable: $Y$

Method: Least Squares

Date: 08/21/14 Time: 16:03

Sample: 158

Included observations: 58

\begin{tabular}{lrrrr}
\hline \hline \multicolumn{1}{c}{ Variable } & Coefficient & Std. Error & t-Statistic & Prob. \\
\hline \hline C & 9.722333 & 1.905452 & 5.102376 & 0.0000 \\
T & -5.579500 & 2.694717 & -2.070533 & 0.0432 \\
X & -5.591507 & 2.139603 & -2.613339 & 0.0116 \\
\multicolumn{1}{c}{ TX } & -4.594500 & 3.025855 & -1.518414 & 0.1347 \\
\hline \hline R-squared & 0.614611 & Mean dependent var & 0.675983 \\
Adjusted R-squared & 0.593201 & S.D. dependent var & 7.317852 \\
S.E. of regression & 4.667386 & Akaike info criterion & 5.985547 \\
Sum squared resid & 1176.363 & Schwarz criterion & 6.127647 \\
Log likelihood & -169.5809 & Hannan-Quinn criter. & 6.040898 \\
F-statistic & 28.70608 & Durbin-Watson stat & 2.198477 \\
Prob(F-statistic) & 0.000000 & & \\
\hline
\end{tabular}


Filipović S., Miljković M.:Transition Economies During Global Economic Crisis...

The following equation is estimated:

$$
Y_{i t}=9.722-5.591 * X_{i}-5.579 * T_{t}-4.594^{*} X_{i}^{*} T_{t} .
$$

The estimated value of the parameter $\beta_{3}$ which amounts to -4.594 means that the real GDP growth rate in the year 2009 as compared with the year 2008 in the group of countries with worse transition progress was by 4.594 percentage points higher than in the group of countries with better transition progress. It means that the transition economies which advanced in implementation of transition reforms suffered more from the consequences of the global economic crisis in its first wave during 2009 than other countries which were at the beginning of the transition process.

Thereby, the $p$-value of the dummy variable which denotes the interaction of dummy variables $X_{i}$ and $T_{t}$ and amounts to 0.1347 indicates the statistical significance of the given conclusion at the confidence level of $85 \%$.

The obtained results are also illustrated in the following chart.

Figure 2. The illustrated results on the difference in the intensity of the shock in 2009

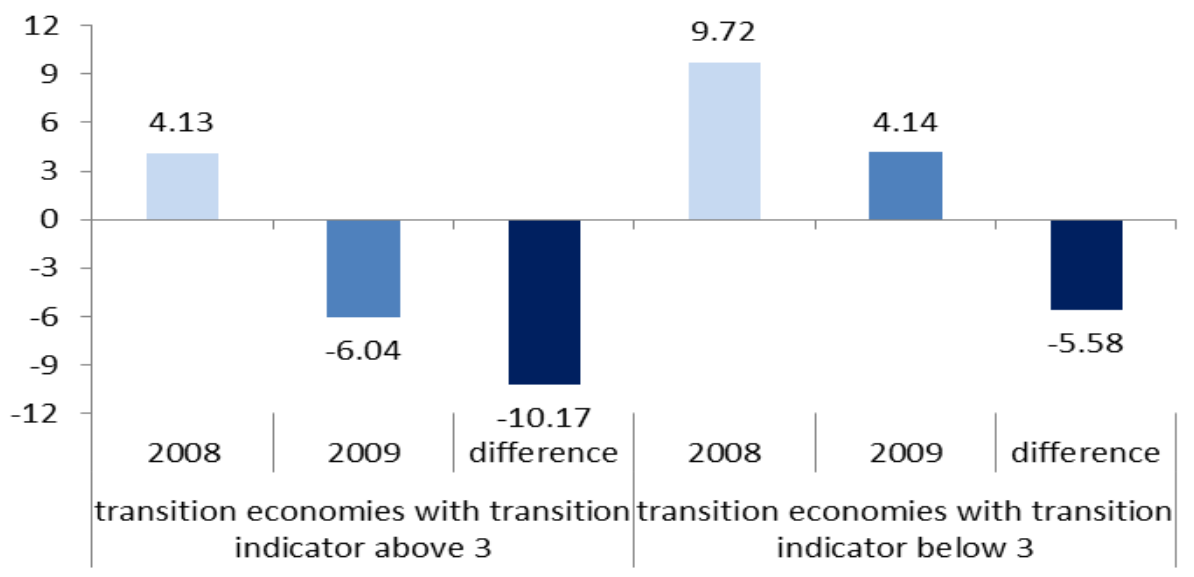

Source: Author's calculation

The empirical results calculated by applying ordinary least squares method on the equation (2):

$$
Y^{\prime}{ }_{i t}=Y_{0}+Y_{1}{ }^{*} X_{i}+Y_{2}{ }^{*} T^{\prime}{ }_{t}+Y_{3}{ }^{*} X_{i}{ }^{*} T^{\prime}{ }_{t}+\varepsilon_{i t},
$$

are presented in the Table 4. 
Filipović S., Miljković M.:Transition Economies During Global Economic Crisis...

Table 4. The empirical results on the difference in overcoming the negative effects of the crisis in the five-year period 2009-2013

Dependent Variable: Y'

Method: Least Squares

Date: 08/21/14 Time: 16:07

Sample: 158

Included observations: 58

\begin{tabular}{lrlrl}
\hline \hline \multicolumn{1}{c}{ Variable } & Coefficient & Std. Error & t-Statistic & Prob. \\
\hline \hline \multicolumn{1}{c}{ C } & 9.722333 & 4.945619 & 1.965847 & 0.0545 \\
T' & 21.66816 & 6.994162 & 3.098035 & 0.0031 \\
\multicolumn{1}{c}{ T'X } & -5.591507 & 5.553359 & -1.006869 & 0.3185 \\
\multicolumn{1}{c}{-18.67492} & 7.853636 & -2.377869 & 0.0210 \\
\hline \hline R-squared & 0.314317 & Mean dependent var & 8.716199 \\
Adjusted R-squared & 0.276223 & S.D. dependent var & 14.23948 \\
S.E. of regression & 12.11424 & Akaike info criterion & 7.893113 \\
Sum squared resid & 7924.765 & Schwarz criterion & 8.035213 \\
Log likelihood & -224.9003 & Hannan-Quinn criter. & 7.948464 \\
F-statistic & 8.251190 & Durbin-Watson stat & 1.773284 \\
Prob(F-statistic) & 0.000130 & & \\
\hline \hline
\end{tabular}

The following equation is estimated:

$$
Y_{i t}^{\prime}=9.722-5.591^{*} X_{i}+21.668^{*} T^{\prime}{ }_{t}-18.674^{*} X_{i}{ }^{*} T^{\prime}{ }_{t} .
$$

The estimated value of the parameter $\gamma_{3}$ which amounts to -18.674 means that the cumulative real GDP growth rate in the period 2009-2013 as compared with the year 2008 in the group of countries with worse transition progress was by even 18.674 percentage points higher than in the group of countries with better transition progress. It means that the transition economies which advanced in implementation of transition reforms suffered more from the consequences of the global economic crisis in the five-year period after the first wave than other countries which were at the beginning of the transition process.

Thereby, the $p$-value of the dummy variable which denotes the interaction of dummy variables $Z_{i}$ and $T_{t}$ and amounts to 0.0210 indicates the high statistical significance of the given conclusion at the confidence level of $5 \%$.

The obtained results are also illustrated in the following chart. 
Filipović S., Miljković M.:Transition Economies During Global Economic Crisis...

Figure 3. The illustrated results on the difference in overcoming the negative effects of the crisis in the five-year period 2009-2013

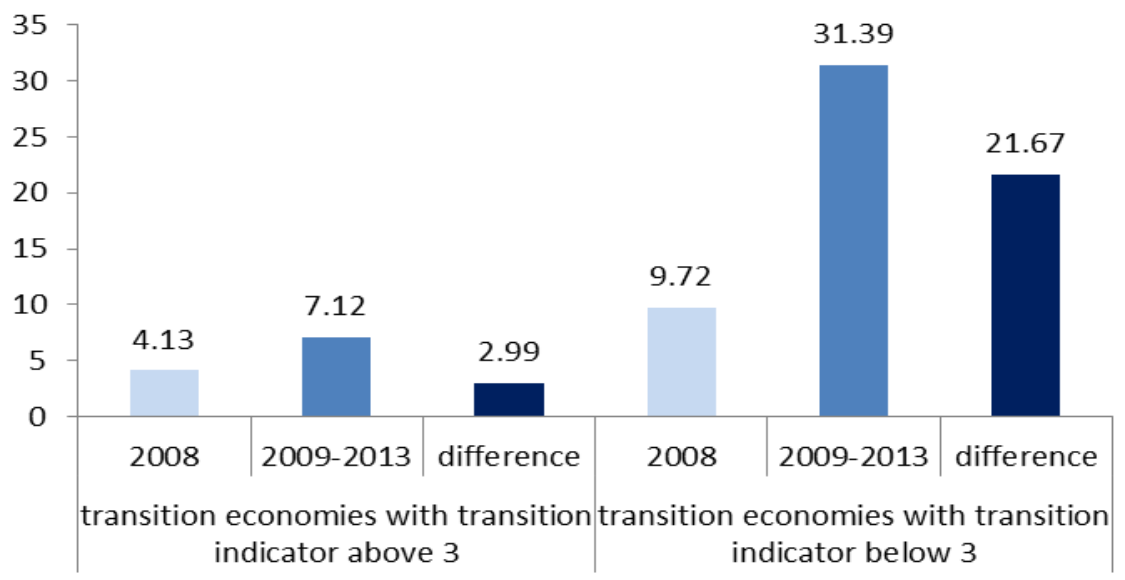

Source: Author's calculation

\section{Conclusions}

Since 2000, structural reform in most transition countries has showed stagnation, except the Western Balkans where market reform has been encouraged as requested by EU integration process. Not so strong political institutions resulted in passive reforms in CIS countries. Market reforms in new EU member states were stopped being supported due to crisis and austerity.

Although not directly exposed to risky mortgages and related assets, transition economies were significantly influenced by the global financial crisis due to being dependent on external capital. The result was a classic "sudden stop" experienced by many transition countries. This applied not only for new member states and SEE countries which were overall net importers of capital, but also for some resource-rich economies (Kazakhstan and Russia) with the government as the net exporter of capital.

The empirical analysis conducted in this paper is based on a sample of 29 countries in transition and showed that economies that have been advanced in the implementation of the transitional reforms (transition indicator greater than 3) were more exposed to the first impact of the global economic crisis of 2009. In addition, this subset of countries in transition with more difficulties overcame the crisis in the five-year period 2009-2013 as they showed by 18 percentage points lower cumulative rate of growth in those five years than the 
Filipović S., Miljković M.:Transition Economies During Global Economic Crisis...

transition countries that advanced less in the implementation of the transitional reforms.

Limitation to growth existed before the crisis and is now present unchanged (political instability, low level of competiveness and governance, etc.). Strengthening of legal systems and the rule of law, strengthening intellectual property rights, and easing investment requirements should be incorporated in further reforms. It can be finally concluded that growth model based on external finances is no longer valid and that these economies should find the new approach.

In terms of external economic shocks such as the global economic crisis, state intervention is necessary and inevitable in order to ensure economic growth and social development in a broader context, ranging from employment, growth and structural changes to the health, education and social welfare policy. Uzbekistan can be the perfect example where the state played an important role in preventive actions against crisis in 2008 by implementing the anti-crisis action plan, and was among few countries that avoided the harsh impact of the crisis. Also, the recovery from the economic crisis of the 1930s and the economic reconstruction after the World War II were carried out in the spirit of a strong state intervention and it can be concluded that the government support is necessary in a crisis situation.

\section{References}

Babetskii, I., \& Campos, N.F. (2007). Does Reform Work?, An Econometric Examination of the Reform-Growth Puzzle. InIZA Discussion Paper. No.2638.

Berg, A., Borensztein, E., Sahay, R., \& Zettelmeyer, J. (1999). The Evolution of Output in Transition Economies: Explaining the Differences. In IMF Working paper. WP/99/73.

Carlos-Alberto, R.A. (2011). From Washington Consensus to Post - Washington Consensus: Consequences in Transition Economies. European Perspectives, 3(1),

de Melo, M., Denizer, C., Gelb, A., \& Tenev, S. (2001). Circumstance and Choice: the Role of Initial Condition and Policies in Transition Economies. World Bank Economic Review, 15, 1-31.

-EBRD. (2013). Transition Report - Stuck into transition. Retrieved from www.ebrd.com

Falcetti, E., Lysenko, T., \& Sanfey, P. (2006). Reforms and Growth in Transition: Reexamining the Evidence. Journal of Comparative Economics, 34, 421-445.

Filipović, S. (2012). The influence of the current crisis on Balkan countries on their way to the EU integration processes. InEuropean integration process in Western Balkan Countries. (pp. 670-692). Faculty of Economics of the University of Coimbra.

Filipović, S. (2014). Review of neoliberal concept in the Western Balkan countries. In Thematic proceedings: The great recessiona and crisis of neoliberal economy. (pp. 125-142). Sremska Kamenica: University of EDUCONS. 
Filipović S., Miljković M.:Transition Economies During Global Economic Crisis...

Havrylyshyn, O., \& van Rooden, R. (2003). Institutions Matter in Transition, But so Do Policies. Comparative Economic Studies, 45, 2-24.

Heybey, B., \& Murrell, P. (1999). The Relationship between Economic Growth and the Speed of Liberalization During Transition. Journal of Policy Reform, 3, 121-137.

Josifidis, K. (2005). Neoliberalism - destiny or choice of life in transition. Privredna izgradnja, 47(1-2), 5-16.

Radulescu, R., \& Barlow, D. (2002). The Relationship Between Policies and Growth in Transition Countries. Economics of Transition, 10, 719-745.

Pelipas, I., \& Chubrik, A. (2008). Market Reforms and Growth in Post-socialist Economies: Evidence from Panel Cointegration and Equilibrium Correction Model. In William Davidson Institute Working Paper. Number 936.

Shelburne, R.C. (2009). The Global Economic Crisis and the Transition Economies. In: Presented at the Project LINK Conference, Bangkok, Thailand, October 27. UN discussion paper No. 2010.2.

Shelburne, R.C. (2010). The global financial crisis and its impact on trade: The world and the european emerging economies.

Singh, A., \& Zammit, A. (2010). The global economic and financial crisis: a review and commentary. In MPRA Paper 39052. Germany: University Library of Munich.

Williamson, J. (1990). What Washington means by policy reform. In Latin American Adjustment. How much has happened?. Washington: Institute for International Economics.

Williamson, J. (2004). A Short History of the Washington Consensus. Barcelona: CIDOB.

-World Bank. (2005). Economic Growth in the 1990s: Learning from a Decade of Reforms. 